\title{
ANALISA PEMBEBANAN PADA GENERATOR LISTRIK KAPAL PENANGKAP IKAN STUDI KASUS PADA KM. MARADONA
}

\section{ANALYSIS OF LOAD ON FISHING VESSEL ELECTRIC GENERATOR STUDY CASE ON MV. MARADONA}

\author{
Bobby Demeianto ${ }^{*}$, Riki Peri Ramadani ${ }^{1}$, Iskandar Musa1 ${ }^{1}$, Yuniar Endri Priharanto1 \\ 1Politeknik Kelautan dan Perikanan Dumai, Jl. Wan Amir, No.1, Kelurahan Pangkalan Sesai, \\ Kecamatan Dumai Barat, Kota Dumai, Provinsi Riau, Indonesia \\ *Korespondensi: bobby.demeianto@gmail.com (B Demeianto) \\ Diterima 19 Agustus 2020 - Disetujui 6 Oktober 2020
}

\begin{abstract}
ABSTRAK. Nilai Efisiensi merupakan suatu tolak ukur yang dapat menginformasikan kepada kita bahwa suatu mesin yang beroperasi dapat dikatakan efisien atau tidak. Penelitian ini memiliki tujuan untuk mencari nilai efisiensi generator listrik pada kapal penangkap ikan KM. Maradona. Selain itu penelitian ini juga memiliki tujuan untuk mencari nilai rata-rata presentase pembebanan arus listrik pada setiap phasa pada generator tersebut dan juga mencari nilai rata-rata presentase ketidak seimbangan dari pembagian beban pada instalasi listrik tiga phasa KM. Maradona. Dari hasil perhitungan didapatkan bahwa presentase ketidakseimbangan instalasi listrik tiga phasa KM. Maradona pada saat generator beroperasi bisa mencapai $31,11 \%$. Dari hasil perhitungan juga didapatkan bahwa rata-rata presentase pembebanan pada generator listrik KM. Maradona maksimal adalah senilai $22,35 \%$ dengan nilai arus rata-rata sebesar 25,50 Ampere. Berbanding lurus dengan nilai arus rata-rata maksimal, nilai daya listrik maksimal KM. Maradona hanya berada pada angka 16,80 kVA dengan nilai efisiensi sebesar $22,40 \%$.
\end{abstract}

KATA KUNCI: Listrik kapal penangkap ikan, efisiensi generator, ketidakseimbangan arus listrik

ABSTRACT Efficiency value is a measure that can inform us that a machine that operates can be said to be efficient or not. This study aims to find the efficiency value of the electric generator on the fishing vessel KM. Maradona. In addition, this study also aims to find the average percentage value of electric current on each phase of the generator and also to find the average value of the percentage imbalance of load sharing in threephase electrical installations in KM. Maradona. From the calculation, it is found that the percentage of imbalance of three-phase electrical installations KM. Maradona when the generator operates can reach $31.11 \%$. From the calculation, it is also found that the average percentage load on the electric generator of KM. Maradona maximum value is $22.35 \%$ with an average current value of 25.50 Ampere. Directly proportional to the maximum average current value, the maximum electrical power value of KM. Maradona is only at $16.80 \mathrm{kVA}$ with an efficiency value of $22.40 \%$.

KEYWORDS: Fishing vessel electricity, generator efficiency, current unbalance

\section{Pendahuluan}

Usaha Perikanan di Indonesia semakin menuju ke teknologi perikanan yang modern. Dewasa ini, teknologi perikanan semakin berkembang terutama pada teknologi penangkapan ikan dalam bidang permesinan kapal, sehingga sumber daya perairan diharapkan dapat dimanfaatkan secara optimal. Salah satu teknologi penangkapan ikan yaitu kapal penangkap ikan. Kapal penangkap ikan banyak digunakan nelayan untuk melakukan operasi penangkapan ikan dilaut (Yaqin dkk, 2020). Kapal penangkap ikan dalam melakukan operasi sangat membutuhkan adanya suatu pembangkit tenaga 
listrik. Energi listrik dari pembangkit tenaga listrik dikapal bukan hanya dipakai sebagai penerangan untuk sebuah kapal, tetapi digunakan untuk membantu proses penangkapan ikan. Energi listrik yang digunakan digunakan pada kapal penangkap ikan adalah energi listrik yang dibangkitkan dan didistribusikan sebagai arus bolak-balik. Arus bolak balik digunakan karena arus bolak-balik mudah direkayasa tegangannya sehingga arus bolak-balik dapat dibangkitkan dan didistribusikan secara efisien pada tegangan yang relatif tinggi. Arus bolak balik juga dapat diturunkan sampai tegangan yang dapat digunakan pada beban.

Sistem tenaga listrik adalah sekumpulan pusat listrik dan gardu induk (pusat beban) yang dihubungkan oleh jaringan transmisi sehingga menjadikan satu kesatuan yang berhubungan (Marusadi, 2006). Sistem tenaga listrik merupakan penyediaan tenaga listrik untuk penggunaannya yang diperlukan peralatan listrik. Berbagai peralatan listrik yang saling dihubungkan mempunyai keterkaitan secara keseluruhan sehingga membentuk suatu sistem tenaga listrik.

Salah satu sistem penunjang kerja utama di kapal adalah sistem kelistrikan yang secara umum terdiri dari sumber daya, sistem distribusi, dan peralatan kelistrikan. Daya listrik yang tersedia digunakan untuk memenuhi kebutuhan penerangan, peralatan navigasi, dan komunikasi, sistem alarm dan monitoring, pengaturan udara dan sistem refrigrasi, motor pompa dan permesinan dek hingga propulsi. Sumber tenaga listrik yang memenuhi kebutuhan beban dikapal umumnya menggunakan generator namun pada kondisi tertentu seperti blackout, beban akan disuplai oleh emergency generator atau baterai yang diletakkan di ruangan Emergency source of electrical power (ESEP). (Fahrurozi,Firdaus,Feranita., 2014). Penentuan kapasitas maupun dimensi generator harus disesuaikan dengan kebutuhan, tidak boleh terlalu kecil kapasitasnya dan tidak boleh terlalu besar dalam dimensinya. Oleh karena itu, sistem instalasi yang dibutuhkan tinjauan dari segi keamanan, dan keselamatan awak kapal dan kondisi teknis kapal. Beberapa kejadian kecelakaan kapal yang disebabkan oleh hubungan singkat listrik pada kapal yang mengabaikan peraturan instalasi umum listrik (PUIL) (Ridwan, 2015).

Berdasarkan paparan sebelumnya maka perlu tinjauan instalasi tenaga listrik yang aman dari segi teknis sehingga tingkat kejadian kecelakaan kapal dari segi hubungan singkat dapat diminimalisir. Tinjauan instalasi tersebut dapat diprediksi dengan menganalisa beban yang ada digunakan pada sumber tenaga listrik kapal penangkap ikan. Tujuan dari penelitian yang dilakukan yaitu untuk mengidentifikasi instalasi tenaga listrik kapal dari besaran beban listrik pada generator kapal penangkap ikan dan penentuan tingkat keamanannya.

\section{Bahan dan Metode}

Penentuan pembebanan listrik dilakukan pada KM Maradona di PPN Sibolga, Sumatera Utara yang memiliki spesifikasi generator listrik pada Tabel.1. Penentuan jenis beban alat elektronik yang digunakan pada KM. Maradona diidentifikasi dengan mengumpulkan semua data alat elektronik. Data yang sudah di kumpulkan tersebut digambarkan dengan menggunakan gambar single line diagram untuk mengetahui sistem distribusi kelistrikan pada beban setiap daerah pada KM. Maradona. Metode pengukuran pada penelitian ini yaitu dengan melakukan pengukuran nilai tegangan listrik dan arus listrik setiap phasa pada panel utama menggunakan tang ampare (clamp meter) pada periodik tertentu saat generator listrik KM. Maradona melakukan operasi penangkapan ikan. Pengukuran dilakukan selama 3 hari dengan rentang waktu 11 Jam dari sore hingga pagi.

Tabel 1. Spesifikasi Generator Listrik KM. Maradona

\begin{tabular}{ll}
\hline Keterangan & Spesifikasi \\
\hline Merk & Yamamoto STC 60 kW \\
No.Seri & $0791 / 04$ \\
Faktor Daya & 0,8 \\
Tegangan & 380 Volt \\
\hline
\end{tabular}


Aurelia Journal, Vol. 2 (1): 63-72

\begin{tabular}{ll}
\hline Keterangan & Spesifikasi \\
\hline Kapasitas & $75 \mathrm{kVA}$ \\
Frekuensi & $50 \mathrm{~Hz}$ \\
Jumlah Phasa & 3 Phasa \\
\hline
\end{tabular}

Pengukuran daya listrik dapat ditentukan dengan sumber energi berupa tegangan listrik yang terhubung dari beban yang berasal dari peralatan pada kapal tersebut. Umumnya pada instalasi listrik terdapat 3 jenis daya listrik yaitu daya semu ( $S$ ), daya aktif ( $P$ ), dan daya reaktif ( $Q$ ) yang ketiganya membentuk suatu segitiga daya. Persamaan untuk mencari nilai daya tersebut ditunjukkan pada Tabel 2. Perhitungan efisiensi generator menjadi salah satu tolak ukur yang digunakan untuk mengetahui pembebanan yang ada. Konsep efisiensi generator sangat berhubungan dengan jumlah tenaga yang digunakan dan jumlah tenaga yang dihasilkan. Persamaan untuk menentukan nilai efisiensi generator dapat ditunjukkan pada persamaan 1.

$$
\text { Efisiensi }(\eta)=\frac{\text { power } \text { output }}{\text { power Input }} \times 100 \%
$$

Persamaan 1

Tabel 2. Rumus Daya listrik Arus Bolak-Balik

\begin{tabular}{|c|c|c|c|c|}
\hline No & Nama Daya & Rumus 1 Fasa & Rumus 3 Fasa & Satuan \\
\hline 1 & Daya Aktif $(P)$ & $P=V . I . \operatorname{Cos} \varphi$ & $\mathrm{P}=\sqrt{3} \cdot \mathrm{VL} \cdot \mathrm{IL} \cdot \operatorname{Cos} \varphi$ & Watt \\
\hline 2 & Daya Reaktif (Q) & $Q=V . I . \operatorname{Sin} \varphi$ & $Q=\sqrt{3} . V L . I L \cdot \operatorname{Sin} \varphi$ & VAR \\
\hline 3 & Daya Semu (S) & $S=V . I$ & $S=\sqrt{3} . V . I$ & VA \\
\hline
\end{tabular}

Penentuan presentase pembebanan pada penelitian ini merupakan kegiatan untuk menentukan perhitungan presentase pembebanan perfasanya dengan menggunakan persamaan 2 .

$$
\% b=\frac{\% \mathrm{bR}+\% \mathrm{bS}+\% \mathrm{bT}}{3} \times 100 \%
$$

Persamaan 2

Dimana \%b merupakan persentase pembebanan pada setiap fasa, IPh merupakan arus yang mengalir pada masing-masing fasa dan IFL merupakan arus beban penuh pada generator listrik (Full Load). Selanjutnya penentuan perhitungan ketidak seimbangan pembebanan menjadi faktor yang penting juga dalam penelitian ini. Penentuan ketidak seimbangan pembagian beban pada instalasi listrik tiga phasa perlu diketahui dulu nilai rata-rata arus tiga phasa pada instalasi tersebut dan nilai koefisien ketidak seimbangan pada masing-masing fasanya. Penentuan besarnya arus rata-rata dapat menggunakan persamaan 3

$$
\mathrm{I}_{\text {rata }- \text { rata }}=\frac{\mathrm{I}_{\mathrm{R}+\mathrm{I}_{\mathrm{S}+} \mathrm{I}_{\mathrm{T}}}}{3}
$$

Persamaan 3

Besarnya arus ketika keadaan seimbang pada setiap phasa nilainya sama dengan besarnya nilai arus listrik rata-rata.

$$
\begin{aligned}
& \mathrm{I}_{\mathrm{R}}=a . I \text { dimana } a=\frac{\mathrm{I}_{\mathrm{R}}}{\mathrm{I}_{\mathrm{rata}-\mathrm{rata}}} \\
& \mathrm{I}_{\mathrm{S}}=\mathrm{b} . \mathrm{I} \text { dimana } \mathrm{b}=\frac{\mathrm{I}_{S}}{\mathrm{I}_{\text {rata-rata }}} \\
& \mathrm{I}_{\mathrm{T}}=\mathrm{c} . \mathrm{I} \text { dimana } \mathrm{c}=\frac{\mathrm{I}_{\mathrm{T}}}{\mathrm{I}_{\text {rata-rata }}}
\end{aligned}
$$

Persamaan 4

Persamaan 5

Persamaan 6

Dimana a merupakan koefisien ketidakseimbangan arus fasa $R, b$ merupakan koefisien ketidakseimbangan arus fasa $S$ dan c merupakan koefisien ketidakseimbangan arus fasa $T$. Besarnya koefisien $a, b$, dan $c$ dalam keadaan seimbang adalah 1. Rata-rata ketidakseimbangan beban (dalam\%) ditunjukkan persamaan 7. 


$$
\% \mathrm{TS}=\frac{\{|\mathrm{a}-1|+|\mathrm{b}-1|+|\mathrm{c}-1|\}}{3} \times 100 \%
$$

Persamaan 7

Dengan $\%$ TS $=$ Persentase rata-rata ketidakseimbangan beban .

\section{Hasil dan Pembahasan}

Sistim pendistribusian listrik yang pada KM. Maradona terbilang cukup sederhana, dimana alur proses pendistribusian listrik dari generator dihubungkan ke panel utama yang berisi gawai-gawai pengaman yang langsung terhubung ke beban-beban listrik pada KM. Maradona. Rangkaian sistim instalasi listrik pada di KM. Maradona hanya menggunakan satu buah generator sehingga tidak dilengkapi dengan sistim sinkronisasi. Generator pada KM. Maradona bekerja pada pukul 18.00 sampai dengan pukul 05.00 WIB, hal ini berdasarkan operasi penangkapan ikan KM. Maradona yang melakukan operasi penangkapan ikan pada malam hari sampai dengan pagi hari. Adapun beban listrik pada KM. Maradona didominasi oleh lampu penerangan. Lampu penerangan yang dimaksud selain digunakan sebagai penerangan pada ruang-ruang kapal, juga digunakan sebagai alat bantu dalam operasi penangkapan ikan atau yang pada umumnya digunakan sebagai alat pengumpul ikan.

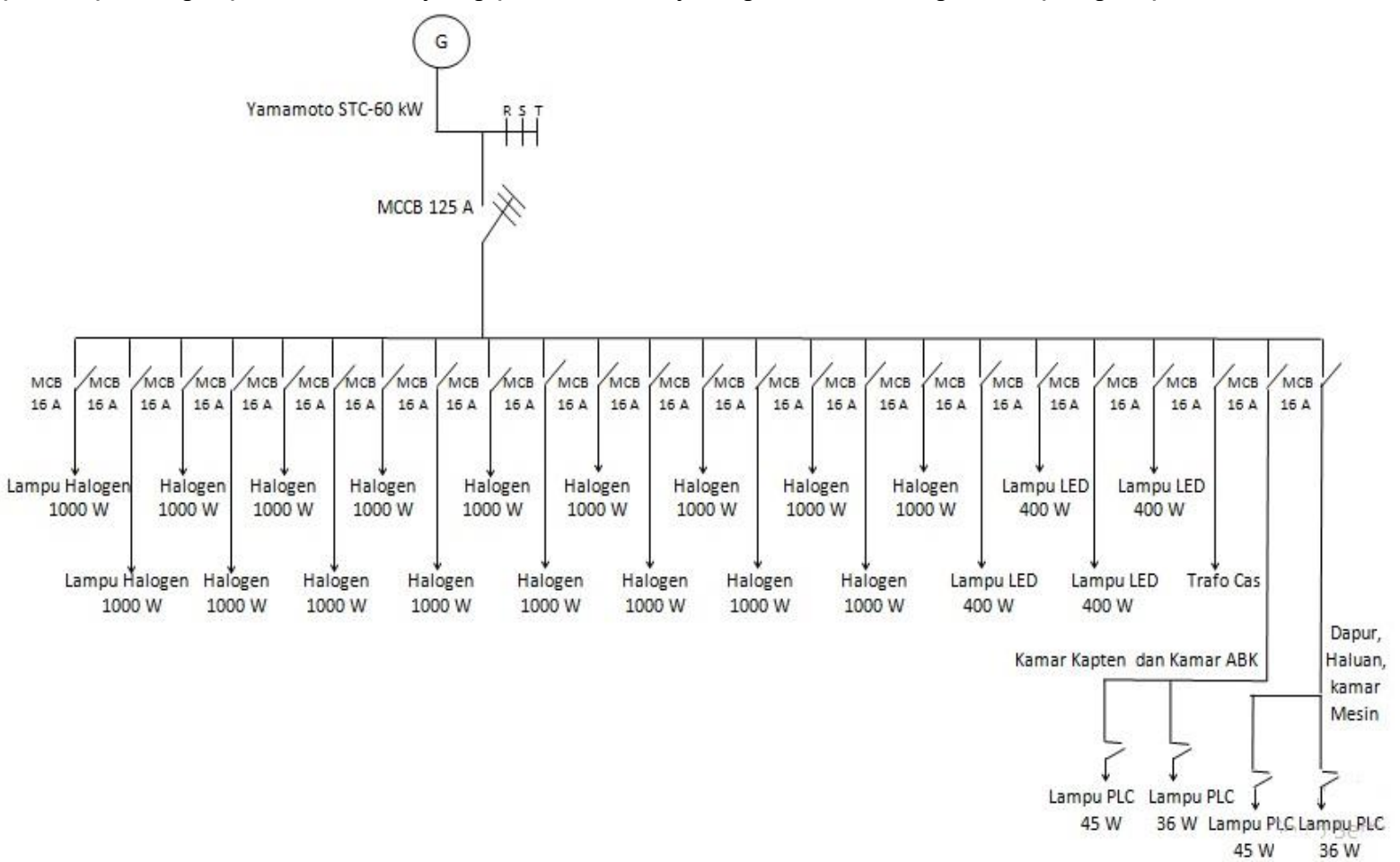

Gambar 1. Single Line Diagram Kelistrikan KM. Maradona

Gambar 1 menunjukkan beban kelistrikan pada KM. Maradona didominasi oleh lampu sorot berjenis halogen berdaya listrik 1000 Watt. Dimana lampu sorot/ flood light digunakan dalam operasi penangkapan ikan sebagai pengumpul ikan tangkapan pada malam hari.

Tabel 3. Lampu Operasi Penangkapan Ikan KM. Maradona

\begin{tabular}{|c|c|c|c|c|c|c|}
\hline No & $\begin{array}{ll}\text { Jenis } & \text { Peralatan } \\
\text { Listrik } & \\
\end{array}$ & Phasa & Daya (W) & $\begin{array}{c}\text { Jumlah } \\
\text { Unit }\end{array}$ & $\begin{array}{l}\text { Jumlah } \\
\text { Daya (W) }\end{array}$ & Keterangan \\
\hline 1. & Lampu Halogen & 1 & 1000 & 17 & 17.000 & Beroperasi \\
\hline 2. & Lampu LED & 1 & 400 & 6 & 2.400 & Beroperasi \\
\hline
\end{tabular}


Adapun beban kelistrikan lain pada KM. Maradona adalah lampu penerangan yang menggunakan jenis lampu PLC dan alat-alat kelistrikan lain yang berfungsi sebagai operasional kapal selain dari operasi penangkapan.

Tabel 4. Beban Listrik KM. Maradona

\begin{tabular}{llccccl}
\hline No & Jenis Peralatan Listrik & Phasa & $\begin{array}{c}\text { Daya Listrik } \\
\text { (Watt) }\end{array}$ & $\begin{array}{c}\text { Jumlah } \\
\text { Unit }\end{array}$ & $\begin{array}{c}\text { Jumlah } \\
\text { Daya (W) }\end{array}$ & Keterangan \\
\hline 1. & Lampu PLC & 1 & 36 & 2 & 72 & Kamar Capt \\
2. & Lampu PLC & 1 & 36 & 2 & 72 & Kamar ABK \\
3. & Lampu PLC & 1 & 45 & 5 & 225 & Kamar Mesin \\
4. & Lampu PLC & 1 & 36 & 2 & 72 & Dapur \\
5. & Lampu PLC & 1 & 45 & 5 & 225 & Deck Atas \\
6. & Trafo Cas Accu & 1 & 350 & 1 & 350 & Kamar mesin \\
7. & Speaker & 1 & 50 & 1 & 50 & Kamar ABK \\
8. & Televisi & 1 & 250 & 1 & 250 & Kamar ABK \\
\hline & Total Daya Listrik (Watt) & & & & $\mathbf{1 . 2 0 6}$ Watt & \\
\hline
\end{tabular}

Data yang terdapat pada Tabel 2., Tabel 3. dan Tabel 4. dapat terlihat bahwa terdapat ketidaksesuaian penggunaan generator listrik pada KM. Maradona dengan jumlah beban listrik yang ada pada kapal tersebut. Jumlah beban listrik pada KM. Maradona apabila beroperasi seluruhnya adalah sekitar 20606 Watt atau 20,61 kW dimana kapasitas generator listrik terpasang adalah sebesar $75 \mathrm{kVA}$ atau apabila asumsi faktor daya yang digunakan adalah 0,8 , maka generator KM. Maradona dapat mengoperasikan eban kelistrikan kurang lebih sebesar $60 \mathrm{~kW}$. Apabila beban beroperasi seluruhnya dalam waktu dan jam yang sama maka efisiensi generator listrik KM. Maradona hanya berada di angka $34,34 \%$. Tetapi kenyataannya, beban kelistrikan pada KM. Maradona tidak beroperasi dalam waktu yang bersamaan atau bahkan hanya beroperasi kurang lebih setengah dari beban kelistrikan yang ada.

\subsection{Pengukuran Nilai Besaran Listrik KM. Maradona}

Pengukuran nilai tegangan dan arus listrik dilakukan selama 3 hari mulai dari tanggal 8 Maret 2020 sampai dengan pukul 2020. Hasil pengukuran dari arus listrik ini berfungsi untuk menganalisa nilai presentase ketidak seimbangan pembagian beban 3 fasa pada generator KM. Maradona dan juga untuk mengetahui nilai presentase pembebanan pada setiap fasanya.

Tabel 5. Pengukuran Besaran Listrik KM. Maradona tanggal 8 Maret 2020

\begin{tabular}{|c|c|c|c|c|c|c|c|c|c|c|c|c|c|c|c|c|c|c|c|}
\hline \multirow{2}{*}{ No } & \multirow{2}{*}{$\begin{array}{c}\text { Waktu } \\
\text { pengukur } \\
\text { an }\end{array}$} & \multicolumn{6}{|c|}{ Tegangan (volt) } & \multicolumn{4}{|c|}{ Arus listrik (A) } & & \multirow{2}{*}{ b } & \multirow[b]{2}{*}{$C$} & \multirow{2}{*}{$\begin{array}{c}\text { \% TS Arus } \\
\text { Listrik }\end{array}$} & \multirow{2}{*}{$\%$ b R } & \multirow{2}{*}{$\%$ b S } & \multirow{2}{*}{$\% \mathrm{~b} \mathrm{~T}$} & \multirow{2}{*}{$\% \mathbf{b}$} \\
\hline & & $\mathrm{R}-\mathrm{S}$ & R-T & S-T & R-N & S-N & T-N & $\mathrm{R}$ & $\mathrm{S}$ & $\mathrm{T}$ & $\begin{array}{l}\text { RATA- } \\
\text { RATA } \\
\end{array}$ & & & & & & & & \\
\hline 1 & 18.00 & 380 & 383 & 383 & 218 & 215 & 219 & 9,40 & 6,40 & 6,80 & 7,53 & 1,25 & 0,85 & 0,90 & & $8,24 \%$ & $5,61 \%$ & $5,96 \%$ & $6,60 \%$ \\
\hline & 19.00 & 378 & 380 & 381 & 215 & 214 & 218 & 29,40 & 23,20 & 16,30 & 22,97 & 1,28 & 1,01 & 0,71 & & $5,77 \%$ & $20,34 \%$ & $14,29 \%$ & $20,13 \%$ \\
\hline 3 & 20.00 & 383 & 383 & 382 & 218 & 217 & 220 & 13,20 & 6,80 & 7,00 & 9,00 & 1,47 & 0,76 & 0,78 & & $11,57 \%$ & $5,96 \%$ & $6,14 \%$ & $7,89 \%$ \\
\hline 4 & 21.00 & 379 & 380 & 380 & 217 & 220 & 220 & 29,90 & 26,70 & 13,60 & 23,40 & 1,28 & 1,14 & 0,58 & & $26,21 \%$ & $23,40 \%$ & $11,92 \%$ & 20,5 \\
\hline 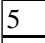 & 22.00 & 379 & 383 & 383 & 217 & 218 & 218 & 27,40 & 24,60 & 14,50 & 22,17 & 1,24 & 1,11 & 0,65 & $23,06 \%$ & $24,02 \%$ & $21,56 \%$ & $12,71 \%$ & 19,4 \\
\hline 6 & 23.00 & 380 & 379 & 383 & 216 & 220 & 216 & 26,50 & 23,60 & 16,20 & 22,10 & 1,20 & 1,07 & 0,73 & $17,80 \%$ & $23,23 \%$ & $20,69 \%$ & $14,20 \%$ & $19,37 \%$ \\
\hline 7 & 00.00 & 381 & 379 & 380 & 214 & 217 & 218 & 26,40 & 25,30 & 17,20 & 22,97 & 1,15 & 1,10 & 0,75 & $16,74 \%$ & $23,14 \%$ & $22,18 \%$ & $15,08 \%$ & $20,13 \%$ \\
\hline 8 & 01.00 & 380 & 380 & 381 & 215 & 216 & 219 & 25,90 & 25,40 & 24,70 & 25,33 & 1,02 & 1,00 & 0,98 & $1,67 \%$ & $22,70 \%$ & $22,26 \%$ & $21,65 \%$ & $22,21 \%$ \\
\hline 9 & 02.00 & 381 & 383 & 381 & 217 & 215 & 217 & 24,80 & 24,60 & 25,20 & 24,87 & 1,00 & 0,99 & 1,01 & & $21,74 \%$ & $21,56 \%$ & $22,09 \%$ & $21,80 \%$ \\
\hline 10 & 03.00 & 381 & 381 & 380 & 218 & 217 & 216 & 24,90 & 24,40 & 25,30 & 24,87 & 1,00 & 0,98 & 1,02 & & 21,8 & $21,39 \%$ & & $21,80 \%$ \\
\hline 11 & 04.00 & 380 & 381 & 380 & 219 & 218 & 217 & 23,80 & 26,40 & 26,30 & 25,50 & 0,93 & 1,04 & 1,03 & $4,44 \%$ & $20,86 \%$ & $23,14 \%$ & $23,05 \%$ & $22,35 \%$ \\
\hline 12 & 05.00 & 383 & 381 & 379 & 218 & 219 & 220 & 12,20 & 9,50 & 8,40 & 10,03 & 1,22 & 0,95 & 0,84 & $14,40 \%$ & $10,69 \%$ & $8,33 \%$ & $7,36 \%$ & $8,79 \%$ \\
\hline
\end{tabular}


Tabel 5. menunjukkan bahwa pada saat pengoperasian generator, nilai rata-rata presentasi pembebanan $(\% \mathrm{~b})$ pada setiap phasa dari generator tersebut sangat rendah sekali dimana rata-rata pada setiap jam nya hanya mencapai angka kurang lebih minimal $7 \%$ sampai dengan maksimal $22 \%$.

Gambar 2, gambar 3, dan gambar 4 menunjukkan bahwa masih tingginya presentase ketidak seimbangan pemakaian beban listrik pada masing-masing phasa pada generator listrik KM. Maradona. Hal ini dapat dilihat bahwa dari ketiga grafik di atas khususnya pada pukul 18.00 WIB sampai dengan pukul 00.00 WIB presentase ketidakseimbangan beban berada pada angka di atas $10 \%$ sampai dengan mencapai nilai $30 \%$. Hal ini diakibatkan oleh pengoperasian lampu penerangan pada saat operasi penangkapan ikan yang tidak seragam pada setiap phasanya. Dari grafik juga dapat terlihat bahwa pada saat penyalaan beban listrik khususnya lampu penerangan untuk operasi penangkapan mayoritas berada pada phasa $\mathrm{R}$ dan phasa $\mathrm{S}$ pada rentang waktu tersebut. Pada pukul $01.00 \mathrm{WIB}$ sampai dengan pukul 04.00 WIB terjadi penambahan nilai arus listrik pada phasa T yang membuat nilai presentase ketidak seimbangan menjadi rendah atau berada di bawah angka $5 \%$.

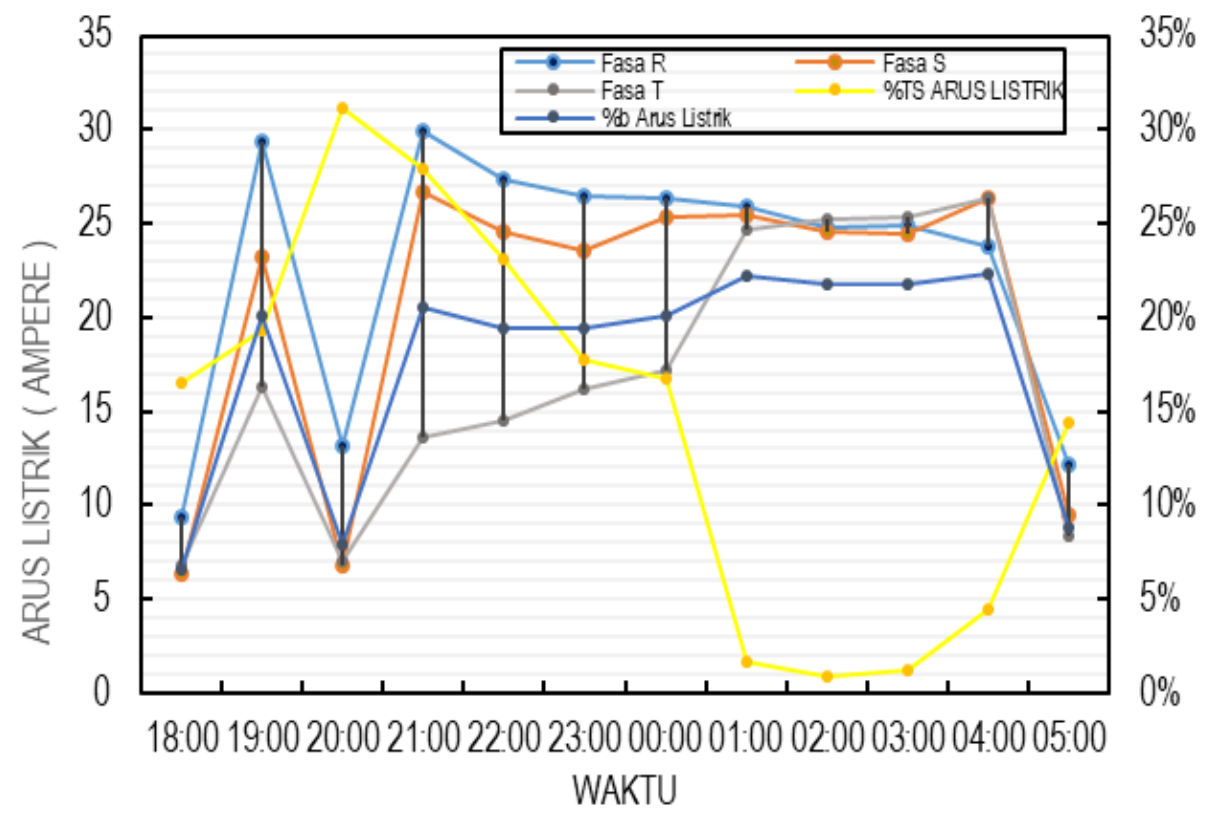

Gambar 2. Grafik Arus listrik KM. Maradona tanggal 8 Maret 2020

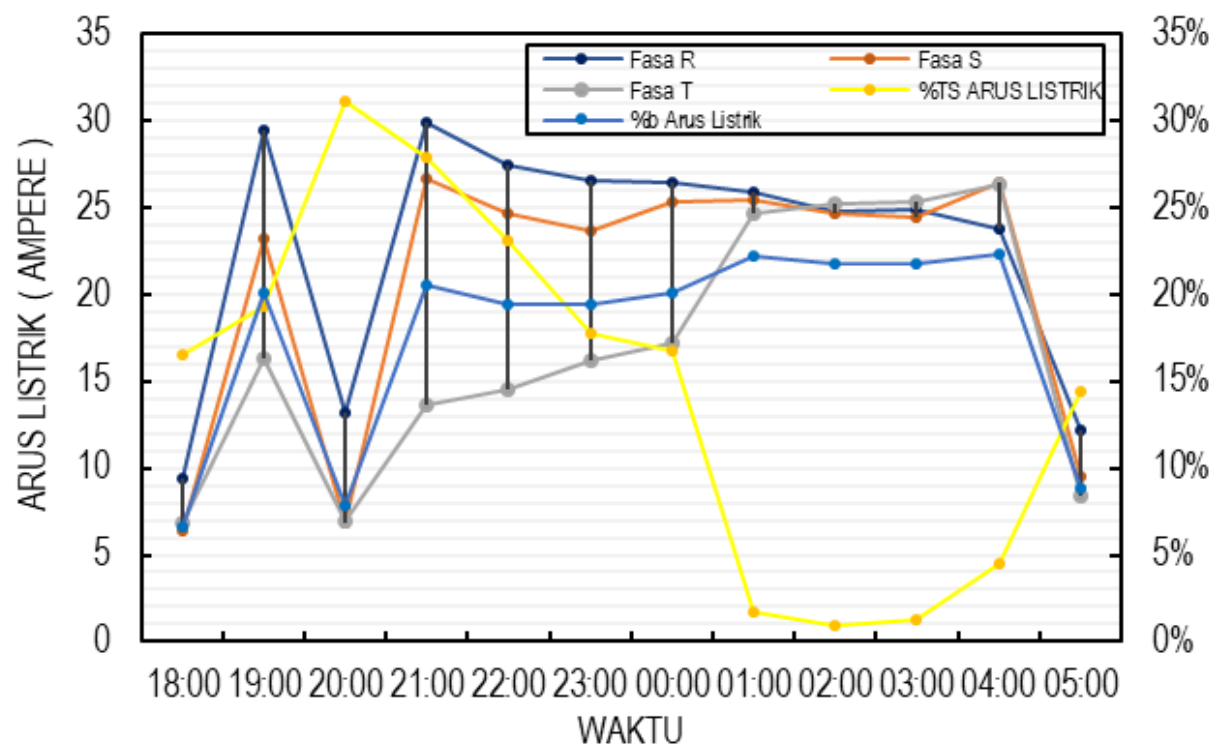

Gambar 3. Grafik Arus listrik KM. Maradona tanggal 9 Maret 2020 


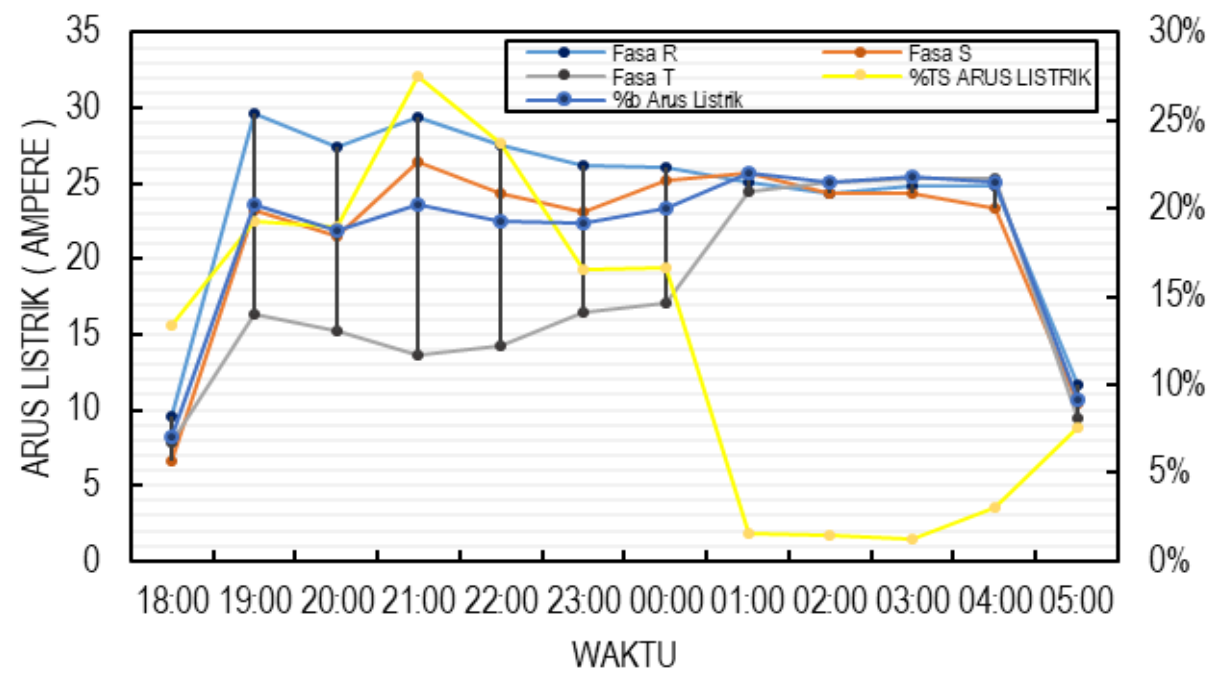

Gambar 4. Grafik Arus listrik KM. Maradona tanggal 10 Maret 2020

Ketiga grafik di atas juga menjelaskan bahwa masih rendahnya nilai presentase pembebanan pada masing-masing phasa pada generator listrik KM. Maradona. Arus beban penuh generator listrik KM. Maradona kurang lebih berada pada angka 114,09 Ampere, tetapi apbila kita lihat pada ketiga grafik di atas bahwa nilai maksimum arus listrik pada setiap phasa hanya mencapai kurang dari 30 Ampere atau kurang dari setengah dari kapasitas generator terpasang. Hal ini juga dapat dilihat dari nilai rata-rata presentase pembebanan yang hanya mencapai nilai maksimal pada angka $22,35 \%$ yaitu pada tanggal 8 Maret 2020 pukul 04.00 WIB atau dapat juga disimpulkan bahwa rata-rata presentase pembebanan arus listrik pada generator KM. Maradona hanya beroperasi dibawah dari $25 \%$ dari kapasitas generator terpasang. Hal ini tentu harus menjadi pertimbangan khusus bagi Kepala Kamar Mesin (KKM) dari kapal tersebut untuk menyarankan adanya pergantian generator listrik dengan kapasitas yang lebih kecil pada kapal tersebut.

\subsection{Perhitungan nilai daya listrik dan efisiensi generator KM. Maradona}

Berdasarkan data tegangan listrik dan arus listrik yang didapat dari hasil pengukuran, maka untuk menentukan daya semu 3 phasa dapat ditentukan dengan rumus $S=\sqrt{3} . \vee . I$ ( VA ), dengan menggunakan tegangan dan arus rata-rata dari pengukuran yang dilakukan setiap jam pada tanggal 8 Maret 2020 sampai dengan tanggal 10 Maret 2020.

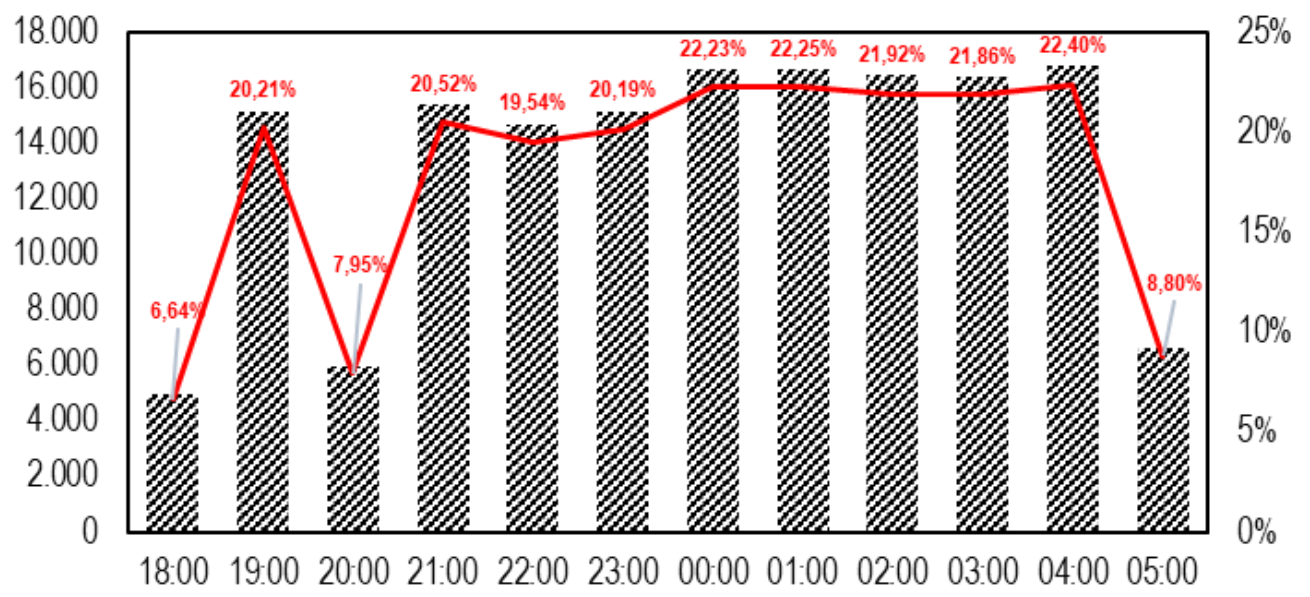

WWX DAYA SEMU ( VA) — EFISIENSI GENERATOR

Gambar 5. Profil Beban Listrik KM. Maradona tanggal 8 Maret 2020 


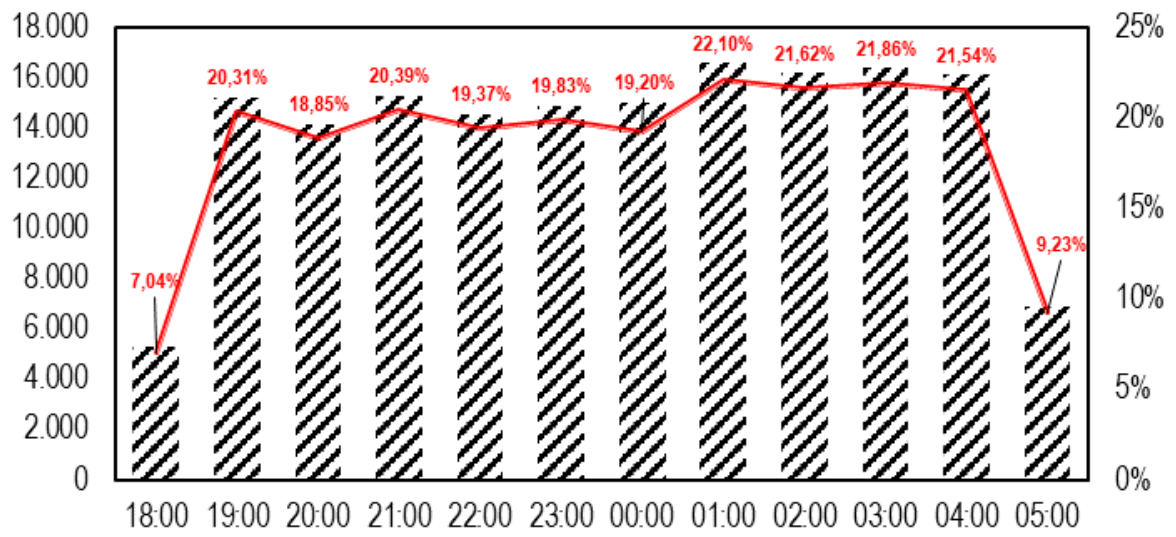

/ $/$ DAYA SEMU (VA) —EFISIENSI GENERATOR

\section{Gambar 6. Profil Beban Listrik KM. Maradona tanggal 9 Maret 2020}

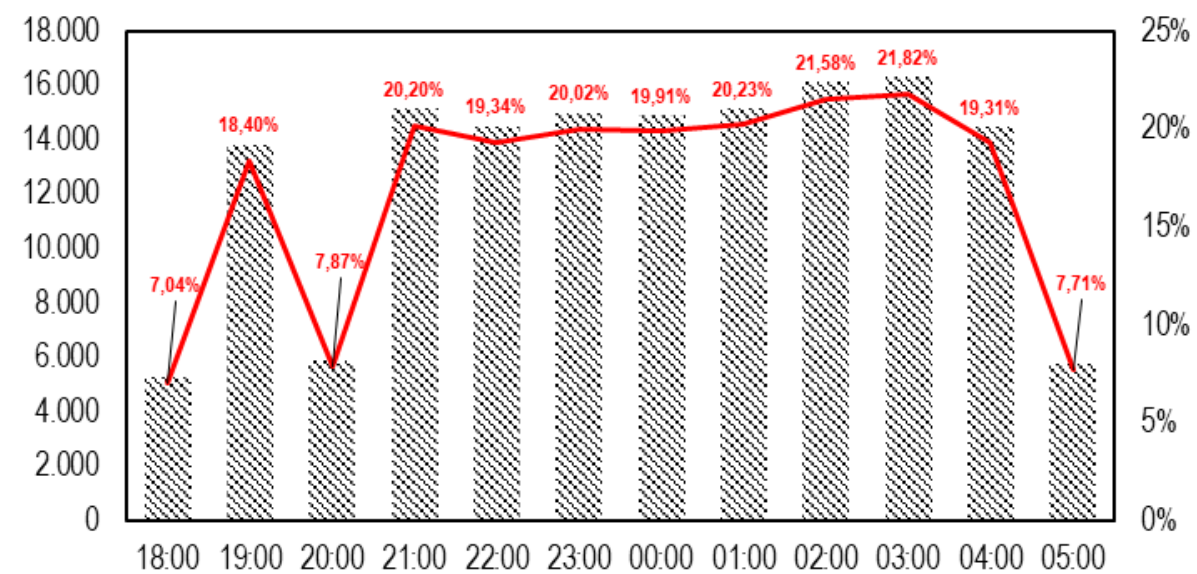

MWN DAYA SEMU ( VA) — EFISIENSI GENERATOR

\section{Gambar 7. Profil Beban Listrik KM. Maradona tanggal 10 Maret 2020}

Berdasarkan hasil perhitungan data besaran listrik yang didapatkan dari hasil pengukuran nilai tegangan dan arus listrik maka dapat terlihat bahwa daya listrik terbesar pada generator listrik KM. Maradona pada tanggal 8 Maret 2020 sampai dengan tanggal 10 Maret 2020 adalah sebesar 16,80 kVA dengan efisiensi generator hanya mencapai nilai $22,40 \%$. Hal ini senada dengan nilai rata-rata presentase pembebanan pada tanggal 8 Maret 2020 yaitu senilai $22,35 \%$. Rendahnya nilai presentase pembebanan arus listrik pada generator akan berbanding lurus dengan rendahnya nilai daya semu dari generator listrik tersebut. Seperti diketahui bahwa kapasitas generator terpasang pada KM. Maradona adalah sebesar $75 \mathrm{kVA}$, dengan daya maksimal selama pengukuran yang hanya mencapai nilai 16,80 kVA menandakan bahwa generator listrik KM. Maradona bekerja dengan nilai efisiensi di bawah $25 \%$ dari kapasitas terpasang.

Gambar 5, Gambar 6 dan Gambar 7 menggambarkan bahwa pemakaian beban listrik harian pada KM. Maradona setiap harinya nya cenderung seragam pada setiap jamnya. Hal ini dikarenakan penyalaan beban listrik pada saat operasi penangkapan ikan yang cenderung sama pada saat operasi. Hal yang menarik dari grafik di atas adalah adanya satu hari dengan penyalaan beban yang tidak sama dengan dua hari lainnya yaitu pada tanggal 9 Maret 2020 pukul 20.00 WIB. Pada tanggal tersebut beban listrik KM. Maradona terlihat lebih tinggi dibanding dua hari yang lain adalah karena pada tanggal 8 Maret 2020 dan 10 Maret 2020 tepatnya pukul 20.00 WIB terjadi gangguan dari lumba-lumba 
yang berkumpul di dekat sumber cahaya dari KM. Maradona, sehingga untuk mengusir kawanan dari lumba-lumba tersebut lampu sorot / flood light yang digunakan sebagai alat bantu untuk operasi penangkapan ikan dimatikan terlebih dahulu. Hal ini tentu mengakibatkan pemakaian daya listrik KM. Maradona mengalami penurunan dengan efisiensi generator berada di bawah angka $8 \%$.

\section{Kesimpulan}

Berdasarkan hasil pengukuran besaran arus listrik dan hasil perhitungan daya listrik didapatkan bahwa rata-rata presentase ketidakseimbangan arus listrik terendah berada pada angka $0,89 \%$ dan rata-rata ketidak seimbangan arus listrik tertinggi berada pada angka $31,11 \%$. Rata-rata presentase pembebanan arus listrik terbesar adalah senilai $22,35 \%$ atau dengan arus listrik rata-rata sebesar 25,50 Ampere. Berbanding lurus dengan nilai arus listrik, pemakaian daya listrik terbesar dalam jangka waktu 3 hari pengukuran dari tanggal 8 Maret 2020 sampai dengan tanggal 10 Maret adalah sebesar 16,80 kVA dengan nilai efisiensi generator senilai 22,40\%. Hal ini menandakan bahwa generator listrik KM. Maradona bekerja dengan efisiensi di bawah nilai $25 \%$ dari kapasitas generator terpasang, sehingga dengan kapasitas generator terpasang sebesar $75 \mathrm{kVA}$ dengan arus beban penuh mencapai 114 Ampere dapat disimpulkan bahwa saat ini generator listrik KM. Maradona mengalami kelebihan pasokan listrik atau dikenal dengan istilah over supply.

\section{DAFTAR PUSTAKA}

Kadir, A. (1996). Pembangkit Tenaga Listrik. Universitas Indonesia (UI Press)

Arismunandar. 2004. Teknik Tenaga Listrik Jilid II. Jakarta. PT. Paradiya Paramita

Demeianto, B. (2019). IImu Listrik Kapal Penangkap Ikan I. Jakarta: AMAFRAD Press.

Feranita, Firadaus, \& Fahrurozi. (2014) Analisa Ketidakseimbangan Beban Terhadap Arus Netral Dan Losses Pada Transformator Distribusi Di Gedung Fakultas Teknik Universitas Riau.

Frank D. Petruzella. (1996). Elektronika Industri. Yogyakarta: Andi Offset

Harten P. Vand and E. Setiawan. (1991). Instalasi Listrik Arus Kuat Jilid II. Bandung. Binacipta

Lin Lou, Fang, dkk. (2005). Digital Power Electronics and Applications. Elsevier (USA). All rights reserved

Marsudi Djiteng. (2005). Dasar Teknik Tenaga Listrik dan Elektronika Daya. Yogyakarta. Jakarta: Erlangga

Ridwan, E. (2015). Analisis Perencanaan Pembagian Beban Dan Instalasi Listrik Pada Hotel Golden Tulip Di Kota Pontianak. Jurnal Teknik Elektro Universitas Tanjungpura, 2(1).

Riyono Yon. (2002). Dasar Teknik Tenaga Tenaga Listrik. Yogyakarta: Andi Offset.

Waluyanti Sri, dkk. (2008). Alat Ukur dan Teknik Pengukuran Jilid I. Departemen Pendidikan Nasional

Weedy. B.M., B.J. Cory, N. Jenkins, J.B. Ekanayake, G. Strbac. (2012). ElectricPower System. British Inggris, John Wiley \& Sons Ltd.

Yaqin, R.I., dkk. (2020). Pendekatan FMEA dalam Analisa Risiko Perawatan Sistem Bahan Bakar Mesin Induk: Studi Kasus di KM. Sidomulyo. Jurnal Rekayasa Sistem Industri. 9 (3): 189-200.

Zuhal. (1995). Dasar Teknik Tenaga Listrik dan Elektronika Daya. Jakarta: Gramedia Pustaka Utama. 
